\title{
ANALYSIS OF THE RELATIONSHIP OF INVESTMENT AND DEMOGRAPHIC FACTORS IN THE DEVELOPMENT OF DEPRESSED REGIONS
}

\author{
Marina PALKINA ${ }^{1)}$, Valentina KISLITSYNA ${ }^{1)}$, Konstantin CHERNYSHEV ${ }^{2)}$ \\ 1) Vyatka State University, Kirov, Russian Federation \\ ${ }^{2)}$ Institute for Demographic Research FCTAS RAS, Moscow, Russia
}

\begin{abstract}
Social and economic spheres of depressed regions develop unfavorably which, in its turn, leads to the negative pace of the national economy development. "Depressed regions" have a higher growth rate of investments in fixed capital per capita than the Russian indicators, but the growth of investment does not cause unambiguous changes in the demographic indicators of development. All "depressed regions" are currently characterized by depopulation and a negative balance of interregional migration. Thus, despite the growth of investment, "depressed regions" are characterized by a reduction in labor and demographic potential. The problem of analyzing the relationship between investment and demographic factors in the development of "depressed regions" is not fully studied today, which undoubtedly affects the quality and effectiveness of decisions made by state authorities to overcome the depressive nature of their economies.
\end{abstract}

Key Words: investment factors, demographic factors, "depressed regions", Russian Federation.

\section{Introduction}

Russia both now and in the past has been characterized by significant interregional socioeconomic inequality and the formation of various problem areas (Grigorieva et al. 2011, Zubarevich 2019). The country has two main categories of problem regions: depressed and underdeveloped regions. The underdeveloped ones are traditionally characterized by a low level of development and they have never had a serious impact on the country's economy. As a rule, they are specialized in agrarian and raw material sectors, they have a low intensity of economic activity, traditionally lower living standards, poor infrastructure development, reduced educational and professional quality of labor resources, socio-economic, political and cultural backwardness. Some regions of the North Caucasus and South Siberia (Ingushetia, Altai, North Ossetia, etc.) are underdeveloped. Another type of problem areas (we will discuss them in this research) are depressed regions. Their main distinguishing feature is that in the past these regions were developed territories and occupied a prominent place in the country, but later they turned out to be in economic decline (Seliverstov et al. 1996). Depressed regions are of particular interest in the development of any state. Depressed regions are territories with an economical state which is currently characterized by lower (comparing to the national average) development indicators. Due to a long depressive situation and accumulation of structural imbalances, the depressed region can move into the category of underdeveloped territories. Russia and a number of other countries of the former eastern bloc have specific features of depression associated with the transition from a planned economy to a market one.

We used the following indicators to identify the depressed subjects of the Russian Federation according to the existing idea of regional depression (Chernyshev 2017):

1. Long-term decline in industrial production, expressed in the industrial production index during the post-Soviet period. This indicator is the main one, as if the region does not have a significant decrease in the volume of industrial production (primarily manufacturing or mining), it 
cannot be considered depressed. To identify subjects of the Russian Federation with pronounced regional depression, we consider a threshold value of the decline indicator in industrial production to be a decrease in industrial production to a level of no more than $75 \%$ compared with 1991.

Table 1

Indicators of socio-economic development of the depressed regions of Russia

\begin{tabular}{|l|c|c|c|c|c|}
\hline $\begin{array}{c}\text { Depressed } \\
\text { regions } \\
\text { of Russia }\end{array}$ & $\begin{array}{c}\text { The } \\
\text { average } \\
\text { population } \\
\text { in 2018 } \\
\text { (thousand } \\
\text { people) }\end{array}$ & $\begin{array}{c}\text { The level of } \\
\text { industrial } \\
\text { production } \\
\text { in 2018 to } \\
\text { the level of } \\
\text { 1991 (\%) }\end{array}$ & $\begin{array}{c}\text { Gross } \\
\text { regional } \\
\text { product } \\
\text { per capita } \\
\text { in 2018 } \\
\text { (thousand } \\
\text { rubles) }\end{array}$ & $\begin{array}{c}\text { The unem- } \\
\text { ployment } \\
\text { rate, } \\
\text { on } \\
\text { average } \\
\text { for 2009- } \\
\mathbf{2 0 1 8} \text { (\%) }\end{array}$ & $\begin{array}{c}\text { The } \\
\text { volume of } \\
\text { industrial } \\
\text { production } \\
\text { per capita } \\
\text { in 2018 } \\
\text { (thousand } \\
\text { rubles) }\end{array}$ \\
\hline Ivanovo region & 1009.2 & 37.6 & 196.0 & 6.1 & 187.8 \\
\hline Oryol Region & 743.3 & 53.0 & 310.4 & 6.5 & 179.9 \\
\hline Smolensk region & 946.1 & 72.0 & 330.8 & 6.2 & 290.8 \\
\hline Pskov region & 633.1 & 74.9 & 259.4 & 7.6 & 194.1 \\
\hline $\begin{array}{l}\text { Volgograd } \\
\text { region }\end{array}$ & 2514.6 & 64.5 & 338.9 & 7.0 & 411.5 \\
\hline $\begin{array}{l}\text { Chuvash } \\
\text { Republic }\end{array}$ & 1227.3 & 62.4 & 242.6 & 6.6 & 189.1 \\
\hline Kirov region & 1277.7 & 59.1 & 260.3 & 6.7 & 220.4 \\
\hline $\begin{array}{l}\text { Ulyanovsk } \\
\text { region }\end{array}$ & 1242.6 & 63.3 & 280.0 & 5.9 & 244.0 \\
\hline Kurgan region & 840.1 & 58.3 & 253.6 & 9.2 & 159.5 \\
\hline Altai region & 2341.9 & 69.0 & 234.9 & 8.1 & 164.6 \\
\hline
\end{tabular}

Source: compiled by the authors on Rosstat (2019)

2. The volume of gross regional product per capita is significantly lower than the average Russian level. We believe that it is incorrect to consider depressed a region where there is a decrease in industrial production, but the level of gross regional product per capita corresponds to the average Russian level or it even exceeds it. For example, in Moscow, the decrease in industrial production is caused not by economic depression, but by the restructuring of the economy in the course of the post-Soviet period. In the category of depressed regions, we include the subjects of the Russian Federation where the GRP per capita is less than $75 \%$ of the average Russian level.

3. The unemployment rate is not lower than the national average level. Obviously, the decline in production in industrial regions should be accompanied by an increase in unemployment.

4. As an additional criterion, we used the volume of industrial production per capita. The threshold value was more than $30 \%$ in relation to the average level of industrial production per capita in the Russian Federation. This criterion allowed separating the depressed regions with an industrial orientation from the underdeveloped ones.

According to the data for 2016, 2017 and 2018, the list of depressed regions was stable, since 10 constituent entities of the Russian Federation met these criteria (Table 1). Various researchers consider other regions of Russia to be depressed as well. Depressed regions do 
not form significant adjacent areas on the territory of the country and they are mainly located in the European part of Russia.

"Depressed regions", as a rule, are characterized by an acute shortage of resources, which are necessary for overcoming the state of depression and the active growth of their economy in the future. Therefore, the development of measures to change the state of these regions should be based on the maximum possible consideration of the mutual influence of the main socioeconomic development factors (Salik 2004). Therefore, it is important to study the relationship of investment and the demographic factors of "depressed regions" as they represent a problem of high relevance and practical importance for the economy of any modern state.

The purpose of this study is to test the hypothesis that there is a relationship between investment and demographic factors in the development of "depressed regions". For this, the authors have used such parameters as "Investments in fixed capital", "Number of employees", "Share of employees", "Structure of investments" for the analysis.

The scientific novelty of the study is to establish the relationship between these indicators, making it possible to formulate a list of measures of the state investment policy of "depressed regions", the implementation of which will ensure the inflow of investments necessary for the economy of such regions, and a considerable improvement of the demographic situation.

\section{Literature review}

It should be noted that depressed regions were distinguished first by Friedmann in the 1960 s (Friedmann and Alonso 1964, Friedmann 1966). In his research, Friedman proposed the following typology of regions (Sokolov 2016): 1. Core regions, which develop through intellectual and information activities, service industries, and high-tech industries. These regions are focused on the use of advanced world experience, on the creation of basic innovations, on the formation of the necessary business environment and the living environment of local communities. 2. Ascending regions - their development is mainly due to the transfer of production from core regions to their territory. 3. Development corridors, which mainly develop due to the advantageous geographical position between core regions or between the core regions and the ascending ones. 4. Regions of the new development of natural resources, which develop due to new agricultural lands, forest and water resources, minerals, etc. 5. Descending or depressed regions characterized by: depletion of natural resources, instability of economic situation, outdated structure of production, lack of susceptibility to innovations, underdeveloped infrastructure and other factors constraining their socio-economic development.

Kukliński (1990) has also distinguished depressed regions in his typology of regions. He identified the following regions: 1 . Creative and innovative regions, which can correspond to the core regions of Friedmann. 2. Adaptive regions, which correspond to the ascending regions, development corridors and the regions of new development in Friedmann's typology. 3. Conservative regions which correspond to the depressed regions of Friedmann (Sokolov 2016).

Depressed regions also include those regions that are characterized by the decline of major industries (Salik 2004). Therefore, we can conclude that depressed regions represent a separate group, which objectively indicates their presence, and it also confirms the relevance and importance of scientific research of this type of region to develop measures to overcome the depressive nature of their economies, taking into account the characteristics of these regions. 
A large number of works are devoted to the development of depressed regions. In particular, some works (Isserman and Rephann 1995, Wood and Bischak 2000, Ezzell et al. 2012) analyze their current state, they identify factors and development trends, including the depressed districts of the Appalachian region, they offer new more accurate indicators for monitoring the socio-economic situation of these districts (Partridge et al. 2008), and they assess the relationship between entrepreneurship and their economic growth (Stephens and Partridge 2011), between infrastructure investments and economic growth (James et al. 2008).

At the same time, according to the analysis of the current state of open-source research, we can conclude that there are no studies which establish the connection between investment and demographic factors in the development of depressed regions. There is a small number of scientific works which, using the example of depressed regions of countries with a postsocialist economy, have analyzed their state and have realized an assessment of the relationship of economic factors of development and the transformation of the demographic sphere of these territories: population reproduction, fertility, migration, unemployment, education, etc.

So, some researchers (Fattakhov et al. 2016, Fattakhov et al. 2017, Fattakhov et al. 2019), on the example of statistical data of two Russian federal districts (Siberian and Volga regions) with several "depressed" regions, have studied the interaction of economic and demographic factors in the process of development of large cities. The researchers have established the existence of such influence. At the same time, we haven't studied the relationship between investment and demographic factors in the development of "depressed" regions in this research.

Other researchers (Burkin et al. 2016) have evaluated the impact of economic factors on the main demographic indicators of the regions using the regression analysis of panel data. The objects of analysis are 80 constituent entities of the Russian Federation, including "depressed" regions. An assessment of such an influence can undoubtedly be used when choosing the methods for managing the social and economic development of "depressed" regions. At the same time, given the importance of a quick and substantial improvement in the demographic situation in these regions, and the need for external investments to get their economies out of the depressed phase of development, the most urgent issue is to establish a connection between the investment and the demographic factors of their development.

Such a relationship is partially considered by Russian scientists (Koreva and Boitcova 2013). The authors have stated that the investment in fixed assets per capita affects the number of births and the migration growth. It should be noted that this study is based on data for the Russian Federation in general, and it does not give an accurate idea of the relationship between these indicators in the case of "depressed" regions.

Krasnoperova (2017) considers the factors, including the demographic ones, which influence the economy of the depressed regions of post-socialist East Germany. Using the methods of regression analysis, the researcher concluded that the factor of the share of youth in the population, as well as a number of other demographic factors: migration growth, the share of students, etc. (Krasnoperova 2017), is crucial in transforming the socio-economic development of depressed regions.

Novotný et al. (2016) study the relationship between demographic development and the economic transformation of small towns (using the example of twelve small towns of Eastern Slovakia) (Novotný et al. 2016). The authors study the data obtained from the 1991 and 2011 censuses on the structure of the population by age, economic activity of the population, and work trips (outbound and inbound). The analysis shows that most small cities are characterized by population stagnation, changes in the job structure and a weak position in the regional economy. It means there is a link between these indicators. 
Hapenciuc and Neamtu (2016) analyze the relationship between the gross domestic product per capita and the proportion of people with higher education, comparing the levels of education and economic development for 2000-2014 in the Romanian regions. Scientists have analyzed the relationship between the share of population with higher education and the gross domestic product per capita (Hapenciuc and Neamtu 2016). The results of the study state that the regions where the proportion of the population with higher education is low, there is a low gross domestic product per capita. If there are a large number of people with higher education in the region, its gross domestic product is bigger.

Hapenciuc et al. (2016) examine the relationship between the following indicators: "unemployment rate", "participation in education and vocational training", "employment percentage", and "gross domestic product" for 2000-2014, in order to identify the differences between regions in Romania (Hapenciuc et al. 2016). The authors present three categories of regions: in a favorable position, intermediate and in an unfavorable position.

Summarizing the foregoing, we have come to the following conclusion: the relationship between investment and demographic factors in the development of depressed regions hasn't been fully studied by foreign and Russian scientists; depressed regions, as an object of study, have not been fully considered. It confirms the high relevance and practical significance of this research.

\section{Methodology}

The present study has established the connection of investment factors with the number of employed people with the help of the pair correlation analysis. The pair correlation analysis, as a method of mathematical statistics, allows establishing a statistical relationship between two random variables. It is assumed that a change in one value leads to a systematic change in another value.

"Investments in fixed assets in de facto prices (million rubles)" and the "Number of employees at the age of 15-72 (thousand people)" were chosen as studied parameters. The correlation analysis was carried out from the point of view of the studied regions in the period from 2000 to 2018. The pair correlation coefficient was interpreted by the Cheddok scale. Thanks to the Cheddock scale, it becomes possible to transfer the quantitative value of the relationship of factors into a qualitative characteristic. The extreme values of the scale are weak coupling with a correlation coefficient from 0.1 to 0.3 and very high coupling with a coefficient from 0.9 to 0.99 .

We carried out an one-factor analysis of variance in the PPP Statistica10RU in order to identify the most significant investment factors which influence the employment level of the studied regions. The main aim of this analysis is to find out how significant the difference between the averages is, with the help of comparison and the analysis of sample variances. Moreover, we have taken the specific part of the working population as a dependent variable in order to avoid the "population of the region" factor, which is mostly determined by the size of the Russian Federation subject.

We have assessed the influence of investments in fixed assets by types of fixed assets, ownership, sources of financing and types of economic activity. Thus, categorical predictors were these variables, also expressed in relative terms as a share in the investment structure. All variables used for the analysis were encoded on a scale of 1-2, where code 1 was assigned to variables with lower value, and code 2 was used for variables with a higher specific weight. The confidence limits (confidence interval) were reduced to $90 \%$ due to the limited number of observations. The results were analyzed according to the variation (SS) and confidence level 
indicators $(p)$. The total variation was divided by the sum of squares due to intragroup and intergroup variability. When the intragroup variation exceeded the intergroup variation, we made a conclusion about the significant influence of other uncontrollable factors that were not considered in the analysis. The $\mathrm{p}$-level value for the studied variable, less than the declared 0.10 , indicated the significance of this variable. We have confirmed the statistical significance of the considered factor by highlighting it in red.

\section{Results}

To establish the relationship between the studied values, we calculated the correlation coefficient for the period from 2000 to 2018, i.e. for 19 years. Table 2 demonstrates the results of the correlation analysis of the studied regions.

Table 2

Results of the correlation analysis

"Number of Employees" - "Investments in fixed assets"

\begin{tabular}{|c|c|c|c|c|c|}
\hline Year & $\begin{array}{c}\text { Correlation } \\
\text { coefficient }\end{array}$ & Year & $\begin{array}{c}\text { Correlation } \\
\text { coefficient }\end{array}$ & Year & $\begin{array}{c}\text { Correlation } \\
\text { coefficient }\end{array}$ \\
\hline 2000 & 0.8096 & 2007 & 0.9566 & 2014 & 0.9166 \\
\hline 2001 & 0.8288 & 2008 & 0.9568 & 2015 & 0.8363 \\
\hline 2002 & 0.8694 & 2009 & 0.9152 & 2016 & 0.8372 \\
\hline 2003 & 0.8689 & 2010 & 0.8761 & 2017 & 0.8552 \\
\hline 2004 & 0.9459 & 2011 & 0.9004 & 2018 & 0.9095 \\
\hline 2005 & 0.9729 & 2012 & 0.9058 & - & - \\
\hline 2006 & 0.9651 & 2013 & 0.9520 & - & - \\
\hline
\end{tabular}

The values of the pair correlation coefficients, ranging from 0.81 to 0.97 , indicate the presence of a strong positive relationship between such factors as "investment in fixed assets" and the "number of employed population" defined for the studied regions. The coefficient fluctuations reflect a slight change in the strength of communication from "high" to "very high", which is associated with a change in the value of investments, as well as the influence of external variables, such as changes in the age of the population, migration, and others.

But at the same time, a comparison of indicators "Number of employees at the age of 15-72 (thousand people)" (kn) and "Investments in fixed assets in comparable prices (million rubles)" (ki), in 2017 in relation to 2000, showed a disproportion expressed in the fact that if the number of the working population is decreasing, the economy of depressed regions has an increasing volume of investment (Fig. 1).

We explain this result by the fact that recently there has been a constant outflow of the population from the studied regions, accompanied by a decrease in the number of working population, where the most marked negative migration is typical for the Kirov and Kurgan regions. The results are not typical for the Russian Federation as a whole (the investment volume in comparable prices increased by 6.31 times, and the change in the number of working people by 1.05 times).

According to the analysis of variance, the influence of the investment structure by types of fixed assets is insignificant. In all categories of fixed assets (dwellings, buildings - except residential, and structures, cars, equipment, vehicles, etc.), the $p$-level turned out to be higher than the $p=$ 0.1 stated for analysis. It means that the investments in certain types of fixed assets are 


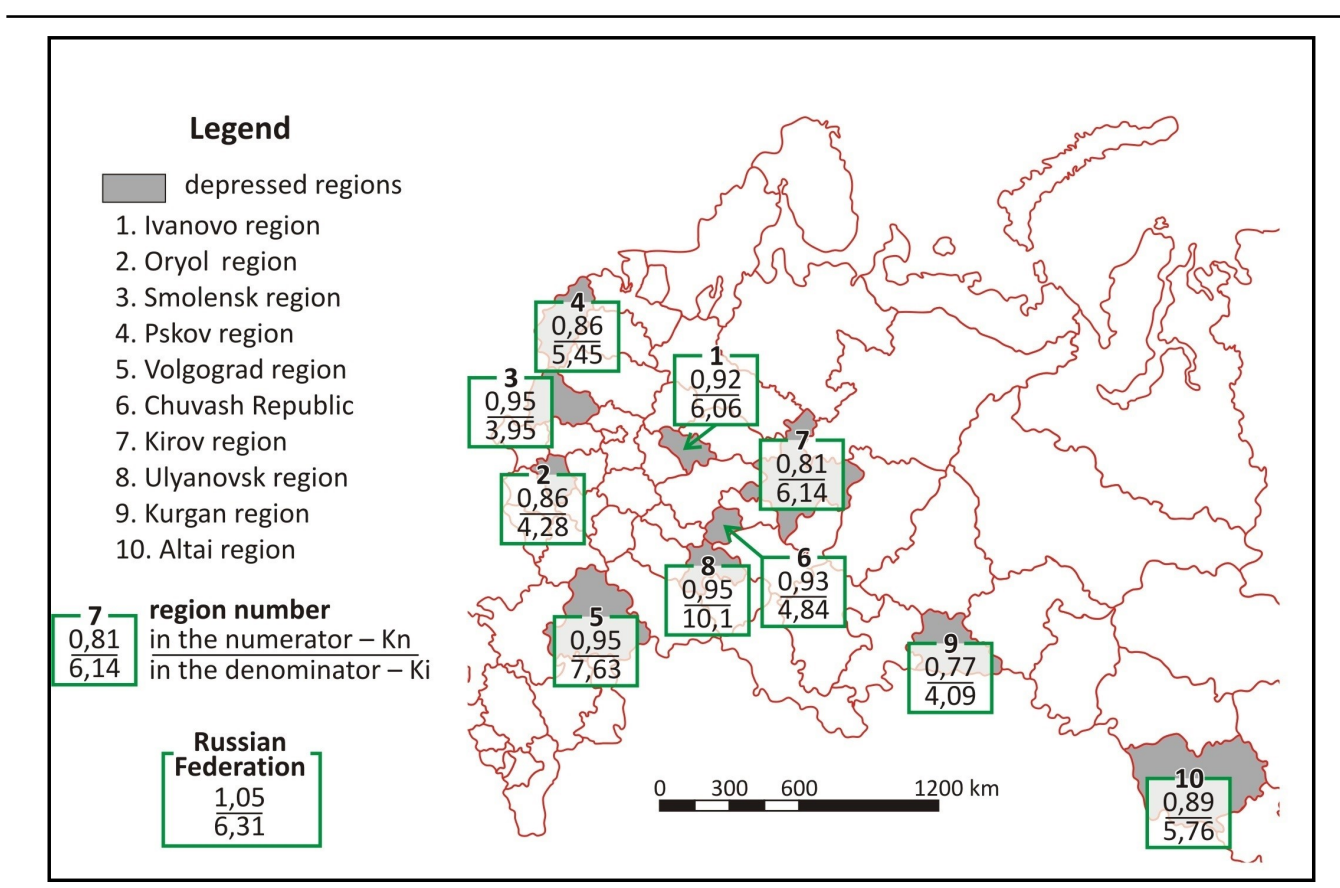

Fig 1 - The ratio of the values of the indicator "Number of employees at the age of 15-72 (thousand people)", in 2017 to 2000 (kn); Ratio of the indicator "Investments in fixed assets in comparable prices since 2000 (million rubles)", in 2017 to 2000 (ki) Source: made by the authors based on Rosstat $(2010,2017,2018)$

equivalent. That is, changing the structure of investments by types of fixed assets does not influence much on the number of working population.

Having analyzed how the investment structure is influenced by ownership, it was revealed that the most significant are the investment resources aimed to develop the objects in Russian property (Table 3), regardless of the type of ownership (state, municipal, private, mixed). The $p$ -level value for the studied factor, equal to 0.039969 , is lower than the $p=0.10$ stated for the analysis, which indicates a high influence of the Russian property variable on the number of people employed in various areas of the national economy. The value of the intragroup variation $S S=1.42857$, which exceeds the intergroup variation $S S=1.07143$, indicates the influence of other factors on the dependent variable.

When analyzing the impact of investments structured by sources of financing, we have found out that the funds from the federal budgets have the greatest influence on "the level of employment of the population". Other factors are also strongly influenced here, as evidenced by the sum of SS squares equal to 1.42857 , due to the intragroup dispersion.

Thus, the most influential are the investment funds from the federal budget which are invested in the development of objects owned by the Russian Federation. Since the investment in fixed assets of enterprises and organizations engaged in the national economy is aimed to develop business entities, and the growth of production volumes unambiguously contributes to the employment development, the first one is a result of increased state control over the distribution of investments, and the second one is a result of increased commercial efficiency, 
the viability and attractiveness of business entities.

It is very important to analyze how investments influence the level of the working activity of the population depending on the investment distribution by type of economic activity. "Production and distribution of electricity, gas and water" and "Transport and communications" turned out to be significant.

Analysis of variance for variables "The proportion of employed population" - "The investment structure in fixed capital by economic activity"

\begin{tabular}{|l|l|l|}
\hline \multicolumn{1}{|c|}{ Indicator } & \multicolumn{1}{|c|}{ SS } & \multicolumn{1}{|c|}{ p } \\
\hline $\begin{array}{l}\text { 1. "Structure of investment in fixed capital by ownership } \\
\text { forms: Russian property" }\end{array}$ & 1.07143 & 0.039969 \\
\hline Other factors & 1.42857 & - \\
\hline $\begin{array}{l}\text { 2. "Structure of investment in fixed capital by sources of } \\
\text { financing: Raised funds (the federal budget)" }\end{array}$ & 1.07143 & 0.039969 \\
\hline Other factors & 1.42857 & - \\
\hline $\begin{array}{l}\text { 3."Economic activities: production and distribution of } \\
\text { electricity, gas and water" }\end{array}$ & 0.90000 & 0.066688 \\
\hline Other factors & 1.60000 & - \\
\hline 4. "Economic activities: transport and communications" & 1.07143 & 0.039969 \\
\hline Other factors & 1.42857 & - \\
\hline
\end{tabular}

Table 4

Distribution of the average annual number of employees by types of economic activity in 2016 (as a percentage of the total number of employees) - fragment

\begin{tabular}{|l|l|c|c|c|c|c|}
\hline & $\begin{array}{l}\text { Subject of } \\
\text { the Russian } \\
\text { Federation }\end{array}$ & $\begin{array}{c}\text { The average } \\
\text { number of } \\
\text { employes } \\
\text { (thousands } \\
\text { of people) }\end{array}$ & $\begin{array}{c}\text { Manufacturing } \\
\text { industries }\end{array}$ & $\begin{array}{c}\text { Wholesale and re- } \\
\text { tail trade; repair of } \\
\text { motor vehicles, } \\
\text { motorcycles, } \\
\text { household goods } \\
\text { and personal } \\
\text { items }\end{array}$ & $\begin{array}{c}\text { Production and } \\
\text { distribution of } \\
\text { electricity, } \\
\text { gas and water }\end{array}$ & $\begin{array}{c}\text { Transport and } \\
\text { communication }\end{array}$ \\
\hline 1. & $\begin{array}{l}\text { Ivanovo } \\
\text { region }\end{array}$ & 536 & 23.9 & 20.2 & 3.8 & 6.0 \\
\hline 2. & $\begin{array}{l}\text { Oryol } \\
\text { Region }\end{array}$ & 385 & 16.5 & 17.8 & 2.9 & 7.6 \\
\hline 3. & $\begin{array}{l}\text { Smolensk } \\
\text { region }\end{array}$ & 519 & 18.9 & 17.4 & 4.7 & 9.5 \\
\hline 4. & Pskov region & 334 & 15.9 & 16.1 & 3.9 & 8.9 \\
\hline 5. & $\begin{array}{l}\text { Volgograd } \\
\text { region }\end{array}$ & 1289 & 13.9 & 19.6 & 3.0 & 8.3 \\
\hline 6. & $\begin{array}{l}\text { Chuvash } \\
\text { Republic }\end{array}$ & 646 & 19.6 & 16.3 & 2.1 & 5.3 \\
\hline 7. & Kirov region & 680 & 19.9 & 17.3 & 3.5 & \\
\hline 8. & $\begin{array}{l}\text { Ulyanovsk } \\
\text { region }\end{array}$ & 653 & 21.9 & 16.5 & 3.5 & 6.7 \\
\hline 9. & $\begin{array}{l}\text { Kurgan } \\
\text { region }\end{array}$ & 411 & 16.2 & 17.3 & 3.5 & 7.4 \\
\hline 10 & Altai region & 1159 & 13.5 & 19.1 & 3.1 & 7.4 \\
\hline
\end{tabular}

Source: compiled by the authors on Rosstat (2017) 
Distribution of the average annual number of employees by types of economic activity in 2018 (as a percentage of the total number of employees) - fragment

\begin{tabular}{|c|l|l|l|l|l|l|l|}
\hline & $\begin{array}{l}\text { The subject } \\
\text { of the Rus- } \\
\text { sian Federa- } \\
\text { tion }\end{array}$ & $\begin{array}{c}\text { The aver- } \\
\text { age annual } \\
\text { number of } \\
\text { employes } \\
\text { (thousand } \\
\text { people) }\end{array}$ & Manufacturing & $\begin{array}{c}\text { Wholesale and retail } \\
\text { trade; } \\
\text { repair of motor } \\
\text { vehicles and } \\
\text { motorcycles }\end{array}$ & $\begin{array}{c}\text { Providing electric } \\
\text { energy, gas and } \\
\text { steam; } \\
\text { air conditioning }\end{array}$ & $\begin{array}{c}\text { Transpor- } \\
\text { tation and } \\
\text { storage }\end{array}$ & $\begin{array}{c}\text { Information and } \\
\text { communications }\end{array}$ \\
\hline 1. & $\begin{array}{l}\text { Ivanovo } \\
\text { region }\end{array}$ & 444.9 & 23.5 & 22.1 & 3.4 & 5.3 & 1.5 \\
\hline 2. & $\begin{array}{l}\text { Oryol } \\
\text { Region }\end{array}$ & 314.5 & 16.7 & 18.4 & 2.5 & 6.3 & 1.9 \\
\hline 3. & $\begin{array}{l}\text { Smolensk } \\
\text { region }\end{array}$ & 432.5 & 19.1 & 18.2 & 4.0 & 8.6 & 2.0 \\
\hline 4. & Pskov region & 282.7 & 15.8 & 16.5 & 2.8 & 8.3 & 1.2 \\
\hline 5. & $\begin{array}{l}\text { Volgograd } \\
\text { region }\end{array}$ & 1140.6 & 13.6 & 19.8 & 2.1 & 7.1 & 1.6 \\
\hline 6. & $\begin{array}{l}\text { Chuvash Re- } \\
\text { public }\end{array}$ & 516.8 & 20.4 & 16.1 & 1.8 & 4.4 & 1.5 \\
\hline 7. & Kirov region & 585.4 & 20.1 & 17.4 & 3.0 & 5.5 & 1.8 \\
\hline 8. & $\begin{array}{l}\text { Ulyanovsk } \\
\text { region }\end{array}$ & 570.9 & 22.0 & 16.7 & 2.8 & 6.2 & 2.1 \\
\hline 9. & $\begin{array}{l}\text { Kurgan } \\
\text { region }\end{array}$ & 326.0 & 18.0 & 17.8 & 2.9 & 6.0 & 1.4 \\
\hline 10 & Altai region & 1023.4 & 13.0 & 18.9 & 6.6 & 1.9 \\
\hline
\end{tabular}

Source: compiled by the authors on Rosstat (2019)

It is impossible to explain the revealed dependence by a higher "number of working population" employed in these industries, since there are industries with a much larger number of employed people, such as "Manufacturing industries" and "Wholesale and retail trade; repair of motor vehicles, motorcycles, household goods and personal items" (Table 4).

We can see a similar picture for 2018. Due to the changes in certain forms of data presentation by Rosstat, Table 5, in addition to the standard type of economic activity "Manufacturing", presents the indicators: "Wholesale and retail trade; repair of motor vehicles and motorcycles", "Provision of electric energy, gas and steam; air conditioning", "Transportation and storage" and "Information and communications activities".

Fig. 2 graphically shows the specific weight of the average annual number of the employees by certain types of economic activity, in comparison.

\section{Discussion}

The authors explain the revealed patterns by the presence of the following premises. The significance of energy, gas, steam and water supply activities is currently increasing. Russia is one of the world's largest energy producers of various types. A leading sector of the economy is also the gas industry. Moreover, the country takes the first place in the world in terms of drinking water and technical water consumption. In addition, there are several thousand enterprises specializing in this field in Russia, and social stability in the society depends on the success of its development, since electricity, gas, water supply of public and residential buildings is a prerequisite for their normal functioning, and the uninterrupted supply of these types of resources to industrial facilities determines the successful and dynamic economic development of Russia (Pronin 2009). 
"Transport and communications also play one of the leading economic, political and strategic roles for the development of the country... The most important branches of the infrastructure of any state are transport, road facilities, communications and information technology. They provide production and interregional ties (Fetisov 2003). This determines the importance of investments in this sector of the national economy, on the quantitative and qualitative component of which the economic well-being of the Russian Federation depends directly.

Our findings confirm a higher proportion of the gross value added of these areas of the economy in the sectoral structure compared with the national indicators, which is typical for most of the studied regions. Thus, for example, if in the Russian Federation, in 2018, the average weight in the structure of gross value added of "Providing electric energy, gas and steam; air conditioning" was $3.5 \%$, in the Ivanovo region this value was $5.0 \%$, in Smolensk region $-8.2 \%$, in Pskov Region - 3,6\%, in Chuvash Republic - 4.1\%, in Ulyanovsk Region $3,6 \%$, in Kurgan Region $-7,8 \%$. In the "Transportation and storage" sector, half of the regions correspond to the identified patterns.

Thus, the increase in investment inflows into the fixed assets of enterprises operating in the studied regions and in industries "Providing electric energy, gas and steam; air conditioning", "Transportation and storage" and "Information and communications", from the federal budget, will increase the number of the working population and, consequently, it will reduce the level of unemployed people, the migration outflow, the full use of labor resources and the capacity, the increase in tax deductions and, in general, the speed development of the economy and the social sphere in the regions classified as "depressed".

\section{Conclusions}

The authors of the study have confirmed that there is a connection between the investment and demographic factors characterizing the development of depressed regions. Also, the authors have established a relationship between the number of working population in the studied regions and the volume of investment in the fixed assets. Also, they have shown the influence of investment inflows, structured by the type of economic activity, on the labor activity of the population in the depressed regions. The most significant turned out to be such types of economic activities as "Production and distribution of electricity, gas and water" and "Transport and communications". According to the research results, the investments from the federal budget aimed to develop the objects owned by the Russian Federation are the most significant in terms of increasing the employment level of the population.

Thus, we can underline that it is impossible to solve the socio-economic problems of "depressed regions", subjects of the Russian Federation, without the participation of the federal center. At this level, it is necessary to develop and to implement a coordinated investment, demographic and migration policy adapted for the depressed subjects of the Russian Federation, which have a common goal - to preserve labor resources, to increase the direct investment and, ultimately, to overcome the economic lag. The main objective of the investment block of such a policy is to reduce the outflow of private capital from depressed areas while increasing investment in the development of federal-owned facilities, primarily infrastructure objects employed in transport, communications, production and distribution of electricity, gas and water, as they demonstrate the highest efficiency in terms of maintaining employment and creating new jobs. The need to create new jobs in depressed regions is proved by research from other countries with economies in transition that have confirmed the limited ability to improve employment by migrating to more developed regions (Fidrmuc 2004). It does not diminish the role of the private sector, where the development of public-private partnerships in the form of vertically integrated structures is a promising direction. Moreover, one of the important tasks is to optimize the size, composition and structure of the public 
sector. Such a policy will contribute to the development of the studied regions, it will avoid their conservation in the existing state, and it will reduce the uneven development of the constituent entities of the Russian Federation. We recommend researching further the mutual influence of other socio-economic factors affecting the development of depressed territories.

\section{References}

BURKIN M. M., MOLCHANOVA E. V., KRUCHEK M. M. (2016), Integral criterion of the influence of social, economic and environmental factors on the regional demographic processes, Ekologiya cheloveka (Human Ecology) 6, 39-46.

CHERNYSHEV K. A. (2017), The study of permanent migration of economically depressed regions, Economic and Social Changes: Facts, Trends, Forecast 10 (4), 259-273.

EZZELL T., LAMBERT D., OGLE E. (2012), Strategies for Economic Improvement in Appalachia's Distressed Rural Counties: An Analysis of Ten Distressed and Formerly Distressed Appalachian Counties, Appalachian Regional Commission, Retrieved from: www.arc.gov.

FATTAKHOV R. V., ABDULOVA L. R., ORESHNIKOV V. V. (2016), Analyzing and assessing the interaction of parameters of demographic and economic development of regions and cities: the Volga Federal District case, Economic Analysis: Theory and Practice 2, 77-90.

FATTAKHOV R. V., NIZAMUTDINOV M. M., ORESHNIKOV V. V. (2017), Toolkit to justify the parameters of the strategic development of the region based on adaptive imitation modeling, Region: Ekonomika i Sotsiologiya 1, 101-120.

FATTAKHOV R. V., NIZAMUTDINOV M. M., ORESHNIKOV V. V. (2019), Assessment of the Sustainability of the Socio-economic Development of the Regions in Russia, The World of New Economy 13 (2), 97-110.

FETISOV V. (2003), The budget system of the Russian Federation: textbook for universities, UNITY-DANA, Moscow.

FIDRMUC J. (2004), Migration and regional adjustment to asymmetric shocks in transition economies, Journal of Comparative Economics 32 (2), 230-247.

FRIEDMANN J. (1966), Regional development policy: A Case Study of Venezuela, The MIT Press, Boston.

FRIEDMANN J., ALONSO W. (eds.) (1964), Regional development and planning: a reader, The MIT Press, Cambridge, MA.

GRIGORIEVA L. M., ZUBAREVICH N. V., KHASAEV G. R. (eds.) (2011), Russian regions: economic crisis and problems of modernization, TEIS, Moscow.

HAPENCIUC C. V., NEAMTU D. M. (2016), Comparative analysis of the geographical disparities regarding the level of education of the population and the level of economic development in Romania and in the regional profile, Ecoforum 5 (2), 35-45.

HAPENCIUC C.-V., NEAMTU D.-M., BEJINARU R. (2016), Comparative statistical analysis of existing differences in the regional development of Romania regarding the main socio-economic indicators, Strategica 560-574.

ISSERMAN A., REPHANN T. (1995), The economic effects of the Appalachian Regional Commission: an empirical assessment of 26 years of regional development planning, Journal of the American Planning Association 61(3), 345-364.

JAMES K., LEIN K., DAY L. (2008), Assessing the growth-inducing impact of the Appalachian Development Highway System in southern Ohio: Did policy promote change?, Land Use Policy 25 (4), 523-532.

KOREVA O., BOITCOVA T. (2013), Analysis and evaluation of the impact of individual factors on the state of the modern demographic situation in the Russian Federation, Naukovedenie 6, 16EVN613.

KRASNOPEROVA I. (2017), Factors of transformation of the socioeconomic development in the depressed regions of Germany, Vestnik Moskovskogo Universiteta, Seriya 5: Geografiya 6, 79-87. 
KUKLIŃSKI A. (1990), Globality versus locality, University of Warsaw, Warsaw.

NOVOTNÝ L., CSACHOVÁ S., KULLA M., NESTOROVÁ-DICKÁ J., PREGI L. (2016), Development Trajectories of Small Towns in East Slovakia, European Countryside 8 (4), 373394.

PARTRIDGE M. D., LOBAO L., JEANTY W., LIONEL J. (2008), "Bo" Beaulieu, and Stephan Goetz. 2008. An Assessment of Alternative Measures for Determining Economically Distressed Counties and Areas in the Appalachian Region, Appalachian Regional Commission, Retrieved from: www.arc.gov.

PRONIN N. (2009), The problem of assessing the risks of investing in the production and sale of electricity, gas and water, Bulletin of the Moscow State Regional University, 44-49.

ROSSTAT (2010), Regions of Russia: Socio-economic indicators, Rosstat, Moscow. ROSSTAT (2017), Regions of Russia: Socio-economic indicators, Rosstat, Moscow. ROSSTAT (2018), Regions of Russia: Socio-economic indicators, Rosstat, Moscow. ROSSTAT (2019), Regions of Russia: Socio-economic indicators, Rosstat, Moscow.

SALIK D. (2004), The Regional competitiveness: some notions, in: Rezep V. J., Competitiveness: a general approach, RECEP's Reports, Rus.-European center of econ. politics.

SELIVERSTOV V., BANDMAN M., GOUZNER C. (1996), Methodological basis for the development of a federal program to help depressed and backward regions, Region: Economics and Sociology, 3-43.

SOKOLOV S. (2016), Socio-economic regionalization of Western Siberia using the methodology of John Friedmann, Economics and the Banking System: Theory and Practice, 345-350.

STEPHENS H. M., PARTRIDGE M. D. (2011), Do Entrepreneurs Enhance Economic Growth in Lagging Regions?, Growth and Change 42 (4), 431-465.

WOOD L. E., BISCHAK G. A. (2000), Progress and Challenges in Reducing Economic Distress in Appalachia: An Analysis of National and Regional Trends since 1960, Appalachian Regional Commission, Retrieved from: www.arc.gov.

ZUBAREVICH N. (2019), Inequality of regions and large cities of Russia: what was changed in the 2010s?, Obshchestvennye nauki i sovremennost 4 (C), 57-70.

Initial submission: 25.05.2019

Revised submission: 14.04 .2020

Final acceptance: 29.05 .2020

Correspondence: Vyatka State University, Moskovskaya Street 36, Kirov, Russia.

Email: palmavik@yandex.ru 